Яковлева О.О., Вознюк Л. А.

\title{
НПЗП-ЕНТЕРОПАТІЯ ТА НУТРІТИВНА ПІДТРИМКА: РЕЗУЛЬТАТИ ТА ПРОГНОЗ
}

Вінницький національний медичний університет ім. М.І.Пирогова Кафредра клінічної фрармації та клінічної фрармакології

Абстракт надруковано в рамках II науково-практичної конференції «АКТУАЛЬНІ ПИТАННЯ НУТРІТИВНОГО ЗАБЕЗПЕЧЕННЯ В КЛІНІЧНІЙ ПРАКТИЦІ», прИсвяченої 40-річчю курсу анестезіології та інтенсивної терапії Вінницького Національного медичного університету ім.М.І.Пирогова", 13-14 жовтня 2016 року, м. Вінниця

НПЗП-ентеропатія - патологія тонкого кишківника, яка виникає в зв'язку з прийомом не стероїдних протизапальних препаратів (НПЗП), характеризується порушенням проникності кишкової стінки з ексудацією білку і діапедезом еритроцитів, що приводять до залізодефіцитної анемії і гіпоальбумінемії, а також до пошкодження слизової оболонки (СО) з розвитком ерозій, виразок і їх ускладнень - кровотеч $\mathrm{i}$ перфорацій, появ циркулярних стриктур і порушенням прохідності кишківника $[1,2,3]$. Питання профілактики та лікування НПЗПентероколопатій, з позицій доказової медицини не розроблені. Не верифіковані фактори ризику розвитку патології. $€$ беззаперечні докази, що харчування впливає на функції багатьох органів і систем, неспецифічний захист та імунітет, процеси регенерації і репарації.

\section{МЕТА ДОСЛІДЖЕННЯ}

Вивчити клінічну ефективність лікувального комплексу, який включає НПЗП і харчових сумішей
«Модулен IBD» і «Пептамен” в комбінованій терапії хворих 3 остеоартрозами (OA), ускладненими НПЗП-ентеропатіями.

\section{ДИЗАЙН ДОСЛІДЖЕННЯ}

Комплексне обстеження 56 хворих 3 ОА, які отримують НПЗП протягом 12 і більше тижнів. У 24 (42,8\%) хворих (19 жінок і 5 чоловіків, середній вік 53,8 $\pm 9,7$ роки) виявлена ерозивна НПЗП-ентеропатія i нутритивна недостатність (HН) легкого і середнього ступеня важкості. Рандомізоване дослідження 2 груп хворих 3 ОА i НПЗПентеропатіями ( 1 i 2 ) 3 оцінкою клінічної ефективності 4-тижневої курсової терапії: НПЗП і НПЗП + ПКП. В якості терапії супроводу дозволявся прийом хондропротекторів.

Критерії включення в дослідження та виключення - співставні з метою дослідження. Використовувались загальноприйняті клініко-лабораторні тести, міні-шкали, опитувальники, антропометричні, лабораторні (загальний білок (г/л), альбумін (г/л), 
абсолютна кількість лімфоцитів (тис. в мкл) показники. Ефективність терапії оцінювалась напівкількісно 3 використанням візуально-аналогових шкал і опитувальників, макроскопічних маркерів НПЗП-ентеропатії і морфологічним параметрам при дослідженні дуоденобіоптатів.

\section{РЕЗУЛЬТАТИ ДОСЛІДЖЕННЯ}

\section{ТА ÏХ ОБГОВОРЕННЯ}

Симптоми диспепсії реєструвались лише у 3 (25\%) хворих, вони зменшились більше, ніж в 4 рази, склали по групі $0,8 \pm 0,11$ бали $(\mathrm{p}<0,05)$. В групі контролю позитивні зміни $\mathrm{CO}$ ДПК були констатовані лише в $1(8 \%)$ i $6(50 \%)$ випадках. В 5 (42\%) випадках зберігались макроскопічні маркери ерозивної НПЗПентеропатії. В 2 групі в динаміці спостереження реєструвалось статистично значиме зменшення морфологічних маркерів запалення при напівкількісному аналізі по групі були вдвічі менш виражені $(\mathrm{p}<0,05)$. В групі хворих, які отримували лише НПЗП зареєстровано збільшення в 2 рази частоти реєстрації атрофічно-

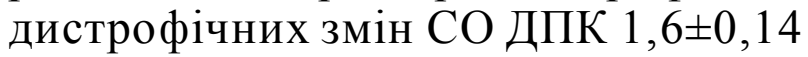
бала $(\mathrm{p}<0,05)$.

\section{ЗАКЛЮЧЕННЯ}

Включення в комплексну терапію хворих з НПЗП-ентеропатією харчових сумішей «Модулен IBD» $\mathrm{i}$ «Пептамен супроводжується позитивною динамікою клінічних, ендоскопічних і морфологічних ознак захворювання 3 урахуванням їх протизапального і ентеропротективного ефекту.

\section{СПИСОК ЛІТЕРАТУРИ}

1. Каратеев A.E., Насонова B.A. Энтеропатия, индуцированная нестероидными противовоспалительными препаратами // Тер. архив. - 2004. № 2. - C. 79-82.

2. Передерий В.Г., Ткач С.М., Марусанич Б.Н. От Maастрихma 1-1996 до Mастрихта 3-2005: десятилетний путь революиионных преобразований в лечении желудочно-кишечных заболеваний // Сучасна гастроентерологія. - 2005. - № 6. - C. 4-8.

3. Goldstein J., Eisen G., Lewis B., et al. Video capsule endoscopy to prospectively assess small bowel injury with celecoxib, naproxen plus omeprazole, and placebo // Clin. Gastroenterol. Hepatol., 2005, P. 3-13. 